\title{
THE LAKESCAPE IN THE EYES OF A TOURIST ${ }^{1}$
}

\author{
ILONA PotockA \\ Department of Tourism and Recreation Centre, Adam Mickiewicz University in Poznań, Poland
}

Manuscript received: June 12, 2013

Revised version: July 5, 2013

Ротоска I., 2013. The lakescape in the eyes of a tourist. Quaestiones Geographicae 32(3), Bogucki Wydawnictwo Naukowe, Poznań, pp. 85-97. 3 figs. DOI 10.2478/quageo-2013-0018, ISSN 0137-477X.

ABSTRACT. Visual-esthetic landscapes values are determining a comfort of leisure in the environment, forms of tourist activities and constitute value as such. The aim of the research is to define how, and which components of lakescape are perceived by tourists, and how it influences on lake tourist activity. Presented paper describes also the role of water itself and the importance of the aesthetics of lakescape in tourist experience. The research of visual landscape values has been conducted for a long time, using different methods. The paper describes, apart from traditional method of inquires, use of eye-tracking to define elements of lakescape perceived by tourists.

KEY WORDS: lakescape, multisensory perception, aesthetic of landscape, eye-tracking

Address of the corresponding author: Ilona Potocka, Adam Mickiewicz University, Department of Tourism and Recreation

Centre, Dziegielowa 27, 61-680 Poznań, Poland, e-mail: ilonek@amu.edu.pl

Houses, waves, clouds, and shadows

(dark blue roofs, russet bricks)

At long last you have become only a gaze

Unrestrained, shining with the black

Tranquil pupils of things.

You will outlast our admiration, our weeping

And our noisy sordid wars.

(Zagajewski 2009, "The view of Delft")

\section{Selected research perspectives of landscape}

Landscape is studied in many scientific disciplines, which explains why so many definitions and classifications of landscape exist. Geography highlights the dualism in the definition of landscape (Richling, Solon 2011). On one hand it is understood as a system of interrelated components which exert an influence on one another (the ecological aspect), and on the other as a physiognomy - the view of a fragment of the space which surrounds us (the visual aspect). In tourism geography, though not as often as in psychology, philosophy or architecture, we also encounter an approach to landscape which takes the mental, symbolic dimension of landscape into account.

\footnotetext{
One can understand the title in different ways: sensu stricto - how a tourist perceives lakescape with a sense of sight or other senses and sensu largo - how he understands it, what it means to him, what its role is in tourist experience.
} 
We are referring here to the perceived landscape as it exists in the consciousness of a tourist (we shall discuss this aspect in more depth later in this article).

In geography, landscapes are classified according to various criteria. For example, in the light of physical-geographical regionalization we can discuss lowland landscapes (here early-post glacial landscapes with surrounding lakescapes), highland and mountain landscapes (Kondracki 2009). Considering the degree to which the environment has been transformed (the historical aspect), certain landscapes can be distinguished - primal, natural, cultural and devastated (Bogdanowski 2000). Depending on function, we can talk about urban, agricultural, industrial or tourist landscapes ${ }^{2}$.

According to Krzymowska-Kostrowicka (1999) the tourist-leisure landscape is a natural or anthropogenic zone, in which tourism is (either permanently or periodically) the dominant function. Considering the extent of human interference in the landscape, tourist landscapes will be above all placed in the group of natural and cultural landscapes. Primal tourist landscapes hardly exist due to the degree of human intervention in the environment and devastated landscapes can be regarded as anti-tourist (possibly pre- or posttourist).

Taking humanistic aspect into account, each landscape can be a tourist landscape if it is perceived by homo viator - a travelling man, tourist, pilgrim. The tourist landscape will then become special, extraordinary, contrary to the normal, everyday landscape of the place of residence (Przecławski 2001; Urry 2007).

In order to consider the topic further it is important to treat the tourist landscape - similarly to real space - in objective and subjective categories. Objective space exists independently of human consciousness. It is specific, identical to whatever fills it. It is the entirety of dependencies or the lack of dependencies between buildings and physical phenomena. Space as a subjective category is defined as a feature of the mind, which permits the structuring of disordered phenome-

2 Geographers are currently discussing whether the notion of a tourist or tourist-leisure landscape is correct. Comments have been put forward by Pietrzak (2010), Plit (2010), Richling (2010), among others. na $^{3}$ (Chojnicki 1999, Lisowski 2003). It is humans who differentiate and categorize space in their minds. Stachowski (1993) highlights the "crucial characteristic of all mental spaces (conscious, recognized, perceived, preferred, actions, etc.), that as they are individual they are not accessible for another person to know". As Krzymowska-Kostrowicka (1997) suggests "to know and understand tourist-recreational behavior in nature, knowledge of its functional and spatial structure is insufficient". It is necessary to supplement it with knowledge of the subjective world of experience, as a result with the ways of interpreting the surrounding reality.

For the purposes of this article the tourist lakescape is understood as the landscape connected with a lake and its immediate surroundings, where tourist phenomena occur. This will be discussed in terms of visual-aesthetics (landscape as scenery and source of emotions) whilst bypassing the geo-ecological aspects.

\section{The role of water and the lakescape in tourist experience}

\author{
There is no denying the attraction \\ of water in landscape
}

(Kaplan et al. 1998)

Water - whether in lakes, rivers or oceans is of fundamental value in tourism. "When people decide to plan vacations and travel for recreation, instruction and pleasure, many have a strong tendency to head to the water" .

Over 2.5 million $\mathrm{km}^{2}$, that is $2 \%$ of the earth's land surface, is taken up by lakes (Choiński

\footnotetext{
The role of a person's everyday external experiences, as well as certain abilities which are fixed in the consciousness to perceive the surroundings are emphasised. Chojnicki (1999), describes space interpreted subjectively, the subject of an individual's or group experience, as phenomenal space. The terms perceptual space and existential space will be used depending on whether space is perceived during an individual's temporary activity, or experienced thanks to signs and symbols.

4 (http://www.waterencyclopedia.com/St-Ts/Tourism.html, date accessed: 31.01.2010).
} 
2007). Taking their immediate surroundings into account it is possible to assume that lakescapes cover about $5 \%$ of the land surface. Lakescapes (limnic) $)^{5}$ is one type of hydrogenic landscape where water is the deciding factor in the genesis, evolution and current processes in the natural environment.

The tourist lakescapes can be considered a natural landscape and also a cultural landscape. As the shores of the lakes have always been a zone of intense settlement, the area around the lakes is also a cultural space, predestined to develop various forms of cognitive tourism (and other forms) in contrast to normal/typical water recreation.

The significant role of lakes in the tourist experience stems primarily from the huge importance of water as such in human life. It is regarded as the origin of all existence, as materia prima and the abundance of all potentiality. It was in water that life on earth began and where also human life begins. The human body consists mainly of water and that is why water, being close to it or looking at it, has such a tremendous though often subconscious meaning for a human being (Smith 2003).

Water (...) can evoke sentimental longing, dreams about a lost paradise and nature, which has a beneficial effect on the physical and psychological condition of an individual

(Kowalski 2002)

Depictions of paradise frequently involve water, and the term "oasis", which refers to a place where water is found, is a synonym of a safe haven. Water remains a symbol of physical, psychological and spiritual purification in all religions. The strong mystic relationship of an individual with a lake (water) is a subject of research, especially in places where lakes are a major asset, for example in Finland where in November 2001 a symposium was held entitled "The spirit of the lake". Tuohino (2003) writes that a lake is not only the shore and the water but a significant place, a complex landscape which becomes a source of strong emotions, tourist experiences of being with

In literature, as well as limnic landscape we also encounter the terms lacustrine landscape or recreational lake systems (Sołowiej et al. 1997; Hall, Harkonen 2006), though they are not synonyms. other people, or in a mystic relationship with nature. The lake "lives" through the meaning it has for people ${ }^{6}$. Although it is not possible to describe the "spirit of a place", genius loci in the language of science, one can sense it or experience it, and it emerges from the style in which the space is filled (Krzymowska-Kostrowicka 1997). Genius loci decides about the uniqueness, singularity and pure magic of a given place.

The role of water can also be discussed in the context of philosophical considerations about the problem of searching for an individual's identity, their place in the world and about experiencing freedom (the essence of travelling?). However, in order to talk about identity it is necessary to experience the integrity of one's body as it is only by becoming the master of one's body that it becomes possible to experience deliverance (Kowalski 2002). Being submerged in water, which by its amorphous nature flows around the human body, confirms the body's boundaries and integrity. Then the pleasure of having a swim (refreshing, cooling property of water) allows one at the same time to fulfill the desire for freedom, distinctiveness and uniqueness. The popularity of diving calls for a different interpretation as the experiences related to going under the water belong to extreme ones, and diving (especially at nighttime) is supposed to be a source of extraordinary experiences of an existential nature. The sight of the water, of the light being reflected on its surface brings about a reflection about oneself and the world ${ }^{7}$. Stormy water provokes meditation over the fragility of human existence. Clear, light-coloured water is perceived in a positive way while cloudy, dark water (mare tenebrarum) evokes respect and stimulates fear. The water

6 Cf. Tuohino (2003), In search of the spirit of the lake. Lakes as an opportunity for tourism marketing, where the author attempts to answer the question whether a landscape framed in a photograph and published in promotional material can become a motivation to travel to the place. Looking at brochures with beautiful landscapes can raise awareness of environmental protection in national parks but it also has an impact on a worse assessment of the less picturesque areas (Levi, Kocher 1999 after Bell et al. 2004).

7 Studies have been conducted concerning the superiority of water properties with respect to reflecting light, as well as a comparative analysis of reflections in glass and water with a clear advantage granted to water (Nasar, Li 2004). 
which reflects the face of a person leaning over it makes one think about transience.

Indeed, the psycho-physiological or psycho-stimulant qualities of water are of substantial importance for the development of lake tourism (cf. Krzymowska-Kostrowicka 1997). It seems in order to consider here to what degree tourists are attracted to water due to being able to enjoy various kinds of tourism, and to what degree they are attracted because of their spiritual and psychological needs water can satisfy ${ }^{8}$. The sight of water and also the sounds it makes (as well as the rustle of reeds or the trees overhanging the shore of the lake) has a relaxing influence on the human mind, and especially on the dweller of urbanized areas. These properties of water can explain the popularity of fishing. One frequently comes across amateur anglers for whom not the "catch" is the most important but rather their willingness to stay near water for a longer period of time. On the other hand, one has to remember about the existence of aqua phobia that is the fear of water which have varied etiology (for example, somebody might have been drowning, or witnessed a flood, etc.). Then the sight of water itself might be an already unpleasant experience.

Waterside areas undoubtedly belong to the most attractive reception areas for tourism. Lake tourism is synonymous with recreation and water sports connected directly with the aquatic area and then the decisive factor in terms of its tourist attractiveness is the quality of the water, the size and shape of the lake, or its trophic type and also climatic conditions. However, a broader context of lake tourism should be emphasized which includes also the activities in the vicinity of the aquatic areas (cf. Smith 2003, Hall, Harkonen 2006, Potocka 2007, Duda-Gromada 2009). Then attractiveness for tourists is determined by nearby cultural attractions, good tourist infrastructure, microclimate, and indeed the harmonious landscape.

In the following part of the article an attempt is made to answer the question: how does the

\footnotetext{
Sometimes it is impossible to differentiate between the two issues since being involved in an activity by, on or under water aims at eliciting emotions, e.g., kite surfing, sailing, diving (this applies to large and deep water areas).
}

tourist perceive the lakescape and what brings about a positive or negative assessment?

\section{The multisensory perception of the lakescape}

\begin{abstract}
All senses are geographical (spatial). Each of them helps people to orientate themselves in space, to become aware of spatial relations and to appreciate advantages of particular places
\end{abstract}

(Rodaway 1994)

Perception is the source of information which ensures survival for humans. It is through perception that humans can infer whether they are dealing with a friend, foe, food or a partner at a particular moment in time (Dennett 1981 after Klawiter 1999), and decide how to react. This perhaps underlies the functionalist-evolutionary approach to landscape (Kaplan, Kaplan 1989), which assumes that a person prefers the landscapes which guarantee basic needs are fulfilled, that is providing food and security 9 .

The perceptual system utilizes various modalities, senses of sight, hearing, smell, taste, somatic senses and others ${ }^{10}$, which have the purpose of gathering information about the environment. The research carried out so far shows that vision is a dominant sense and collects over $85 \%$ of the stimuli coming from the environment ${ }^{11}$.

Landscape perception is a subjective process. The way we "see" the world involves aspects of our experience and memory (Bell et al. 2004). In such a case intentionality becomes a signifi-

This might seem a farfetched conclusion but the fact that lakescapes rich in water and food give a sense of security, the prospect of survival might be the reason why they are frequently chosen as a tourist destination.

10 The somatic senses consist of three separate senses: touch, nociception that is the sense of pain and the sense of temperature; a different category includes the sense of balance and proprioception that is the kinesthetic sense (allowing us to sense the position of our body parts).

11 Other senses respectively claim: 7\% - hearing, 3-5\% - smell, 1-5\% - touch, and 1\% - taste (Visual Landscape... 1994 after Pietrzak 2008). 
cant variable of perception, and it is understood as the agency of the subject who relates to certain meaning, interprets signals which he or she perceives and assigns to them some sense utilizing the available experience (Judycki 2008) ${ }^{12}$. People have different preferences regarding landscape which are determined, to put it in simple terms, by biological factors (e.g. gender, age) and by cultural factors including knowledge, views, values system, education, social background, and others. These personal preferences also undergo changes parallel to one's physical and psychological predispositions at the moment of coming in contact with a landscape ${ }^{13}$.

Yet, the landscape itself also changes. This feature is especially characteristic of aquatic landscapes which are decisively determined by the specificity of water, its amorphous nature and capacity to undergo change, for example its physical state. The perception of the lakescape is determined by many variables, among others by the time of the year (ice and snow on the lake, a hot summer day and a revitalizing swim), time of the day (morning mist, a colorful sunrise or sunset, a reflection of the moonlight), the weather (smooth versus rough lake, clear or cloudy sky, clarity of the air).

It needs to be stressed that the tourist is not only the receiver but also a part of the landscape, its creator, participant, and the central value (Papp 2002). The tourist can be an onlooker but also the part which is looked upon. The presence of other people in the landscape (sometimes desired, e.g., participating in a cultural event, and sometimes not, e.g., when contemplating nature) has a significant impact on our sensual experience, perception. Therefore it becomes essential to consider the phenomenon of perceptual capacity. This is a subjective quality of a tourist experience. Although a place can physically accommodate other tourists, it is no longer as "wild" as it was expected by a tourist communing with nature, which means that the perceptual capacity has been exceeded (Walter 1982 after Urry 2007). In the case of lakes where the tourist movement is very concentrated on and near the shore the

\footnotetext{
2 Cf. Zajadacz, Potocka 2010.

13 This dependence of perception on a variety of factors is called apperception (Winiarski, Zdebski 2008).
}

perceptual capacity (and the physical capacity as well) can be frequently exceeded.

A person can admire a landscape in two ways: statically, that is standing still, e.g., when looking at a lake from the shore, from an anchored boat, or when in motion (a mobile vision), as when walking around a lake or when canoeing, or having a ride in a motorboat; the faster the movement the more intense the sensation ${ }^{14}$. In both cases the tourist is usually a participant in the "spectacle". Even when standing motionless we are looking at a dynamic landscape with the characteristic volatility of the clouds which are additionally being reflected in the water of the lake, with the aquatic recreational activity on the water, and frequently with the presence of other people.

In the light of the research carried out by Krzymowska-Kostrowicka (1997) the attraction to landscapes constitutes one of the major motivators behind tourist activity for over $60 \%$ of tourists. The visual-aesthetic values of lakescapes are a decisive factor which defines the comfort of taking a rest in the environment. These values determine tourist activity and are an attraction in themselves. Urry (2007), contrary to some critical opinions, puts forward a thesis that "a tourist experience is fundamentally a visual experience".

The following part of the article is devoted to a brief discussion of a few notions connected with the visual-aesthetic perception of landscape with reference to how lakescapes are perceived by tourists.

\section{The aesthetics of lakescape}

"Here [by the lake - I.P.] a person open to emotionally tinted aesthetic values comes across an adequate set of accessories for intimate moodiness, where the translucent water, with its green banks, the clouds which find a clear reflection in the smooth but lively surface of the water, the birds flying by. The lake makes us recall the tran-

14 It is worth mentioning that the way the world is perceived has changed over time. It was only during the Renaissance and later on during Romanticism that the love of nature became acknowledged, and visual perception became a legitimate scientific method which replaced the a priori approach to knowledge typical of the Medieval cosmology (Urry 2007). 
sient moments which in a condensed form gather our intimate bond with what appears rarely and moves us, as well as it refers us to the beauty of the water cleansed from passion and shimmering with its green and covered by the sky blue" (Gołaszewska 2000).

The study of landscape considered in aesthetic categories is an interdisciplinary study, where many disciplines overlap, e.g. aesthetics of reality, art history, landscape architecture, philosophy or environmental psychology, and is not an easy study ${ }^{15}$. Canons of beauty change, which is reflected for example by different approaches to nature over the centuries (from fear - biophoby, through admiration - biophilia), the mere sense of beauty is extremely subjective (a trivial sentence saying that "beauty is in the eye of the beholder"), and what is more, "beauty is a thing hard to talk about in human language" (Stróżewski 2002). As Böhme (2002) writes, "for healthy (...) and good life, it is necessary to experience the surroundings with specific aesthetic qualities". Specific - what kind of qualities does it mean? The descriptive approach to landscape assessment emphasizes contrasts of lines, shapes, colors and textures. Natural landscape components satisfy human need for beauty and are preferable to creations of human activity (Bell et al. 2004, Emerson 2005). The physical-perceptive approach emphasizes the role of harmonious utilization of neighboring grounds, orographies, presence of water or vegetation and nature as such (the aforementioned approaches should not be considered separately because they overlap).

The psychological stream contains a number of distinct threads. The biological influences are manifested through preferability of those environments that allow one to function properly and that ensure survival (Kaplan, Kaplan 1989). The authors indicated two dimensions as key in categorization of landscape: contents and spatial configuration. As far as contents are concerned, the most important, positive factor is the presence of nature, the obvious feature of lakescape. Spatial configuration is the dimension described by bipolar qualities: open versus closed and defi-

In 2000 a conference entitled „Water Aesthetics” took place in Finland, and in 2011 there was one in Poland, entitled "Science and beauty". nite versus indefinite space ${ }^{16}$. Observers (tourists) prefer landscapes that are not too open and not too closed, which do not limit the possibility to move freely in space (Bell et al. 2004), furthermore "the sense of depth can be provided by the balance between trees and open areas" (Kaplan et al. 1998). Closed landscapes have a limited visual accessibility. Apart from land coverage, the range of view depends on the topography or access to "sightseeing" spots - either natural (hills, bare and high lakeshores) or "organized" by man (trails around lakes, piers, sightseeing platforms). Considering lakescape in the categories of visual accessibility, definitely desirable are the water areas with average or large surface area, low elongation index, with shores at least partly bare.

This stream includes also the environmental preference matrix of Kaplan and Kaplan (1988), which arranges information dimensions into four main components: coherence - the degree of environment organization and compatibility (the greater coherence, the more an environment is preferable), legibility - the degree of distinctiveness of landscape elements, which is crucial to orientation ${ }^{17}$, complexity - the number and diversity of landscape elements (the level of complexity may be too low for one person and too high for another), and mystery - the feature of landscape arousing the need of penetration (paradoxically, familiarity may also be a positive dimension in a given landscape) (Kaplan et al. 1988).

The second example of psychological approach is environmental aesthetics according to Berlyne (1974), which emphasizes the meaning of a number of factors, i.e. complexity (the degree of diversity of landscape components), novelty (the number of landscape features new or unnoticed before), incongruity (the degree of disharmony between environmental factors and their context) and surprisingness (the degree of inconsistence with expectations towards environment) (Berlyne 1974 as cited in Bell 2004). Considering different psychological exploration types, the most

16 "Though a vast view can be engaging, being in a big outdoor space can be quite daunting" (Kaplan et al. 1998).

17 "For a vista to be engaging, it must have both coherence and focus (...). If there are too many groupings, it is difficult to decide what to look at." (Kaplan et al. 1998). 
beautiful landscape will be deemed the one with average degree of complexity, novelty and surprisingness, while the place with extremely high or low value of these qualities will be assessed negatively.

As it is evident from the above, criteria for assessment of aesthetic value of landscape are diverse and it is difficult to indicate unequivocally which features of space and objects contained in it will evoke positive aesthetic experiences in a tourist. Thus, a lakescape, to be considered beautiful, should be natural and harmonious, as well as highly diverse - horizontally and vertically, which includes among others a developed shoreline (novelty/mystery/surprisingness) and great vertical development (high lakeshores which provide a vast view and make it up at the same time - if we look from the side of the water), with vegetation which does not cover the view, but on the other hand provides safety and intimacy. In the case of lakes with large surface area, the presence of islands will be valuable, as they "break" the openness of space and improve orientation.

Apart from beauty, aesthetic categories include also sublimity, which is a mixture of excitement and fear experienced by a tourist facing the landscape of Nature, especially primal, sometimes appalling. Experiencing extreme feelings of fear and pleasure at the same time (physically impossible?) was of interest especially for psychologists (Furniss 1993 as cited in Macnaghten, Urry 2005). Lakescape can also be the source of sublimity, particularly when we deal with lakes - symbols, e.g. Lake Baikal or Titicaca, but also in contact with "ordinary" lakes, but in extraordinary situations.

Finally, one important remark - not always the presence of a lake (or another kind of water) in landscape guarantees high attractiveness. Polluted water - its smell and color, as well as the sight of strange objects floating in it definitely lowers the quality of the landscape. Kaplan and Ryan (1998) emphasize that attractiveness also depends on the development of lakeshore (or the edge of water other than a lake):

Of particular importance is how water is perceived is the water edge. A waterway that overflows its edge can look less attractive (...). Waterscapes that are particularly appreciated tend to have edges that fol- low a more natural form rather than being bound by straight edges. The presence of vegetation at the edge also can enhance the appearance.

\section{The study of visual landscape with eye-tracking method}

The study of visual qualities of landscape have been conducted for many years with diverse methods (Skarżyński 1992, Śleszyński 1997, Kowalczyk 1992, Kaplan et al. 1988). The article briefly discusses the use of eye-tracking for identification of the lakescape elements which draw tourists' attention ${ }^{18}$.

The first saccadometric research - tracking and recording of the human eye activity - was conducted over 100 years ago, but was very invasive. Over time, the tools have so improved that now it is difficult to see that we are dealing with an eye-tracker ${ }^{19}$. Saccadometers may be mobile (put on the head of the user) and stationary (a monitor with sensors recording eye movement).

Saccadometer records as well as analyses two main components of eye movement (saccades) - intensive eye movements which involve a very fast shifting of the point of gaze concentration from one place to another (the stimuli that reach the brain during saccade movements are not analyzed and there is no cognition) and fixation - the period of gaze concentration on a given object, when a cognitive process occurs, i.e. the information reaches the brain and is processed. The outcome is qualitative and quantitative data - a collection of raw data, which may afterwards be subject to statistical analyses, as well as constitute different measures. One example of such a measure is the number of fixations in the given area - large number of short fixations may indi-

18 The reseach was conducted by Młynarczyk and Potocka in 2010 (Młynarczyk, Potocka 2010, 2011).

19 Saccadometric research is used among others in psychology (cognitive psychology and cognitive science, developmental psychology, experimental psychology and psycholinguistics), emarketing (especially for website assessment), medical diagnostics (e.g. ophthalmology), in applications connected with safety, identification (Duchowski 2007). In tourism this method was used for assessment of tourist websites (Bartkowska 2009, Dobre na pierwszy.... 2010). 

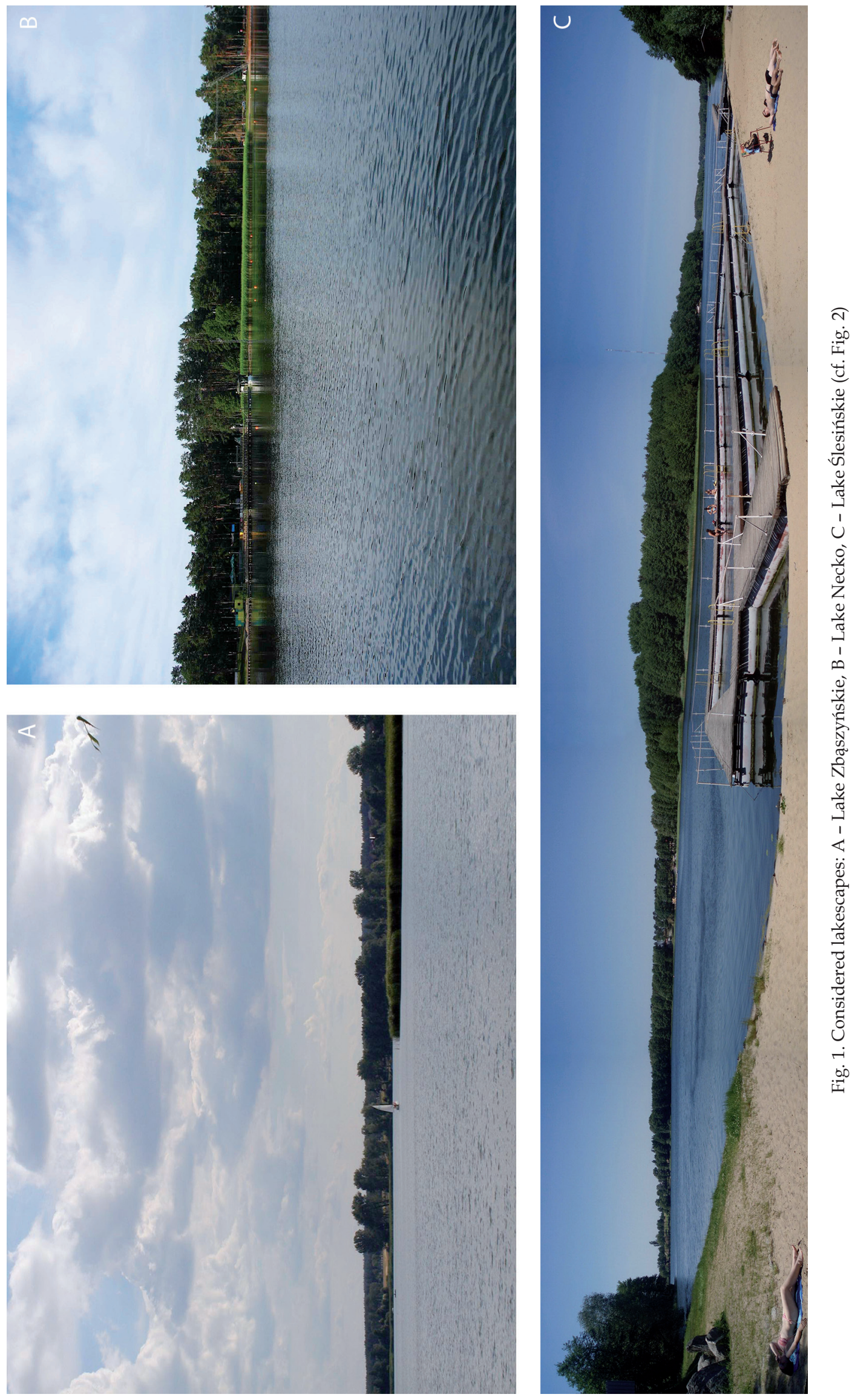
cate difficulties with interpretation of the presented contents (Duchowski 2007).

The purpose of the research was an attempt to indicate the gaze points in the lakescape with the use of an eye-tracker. The research was conducted with the use of a stationary saccadometer ET Tobii $\mathrm{T} 60$, on the group of 36 people $^{20}$. The examination with the recording device was supplemented by a questionnaire, where the participants were asked, which elements may be considered stimulants of tourist attractiveness of the landscapes looked upon, and which may be destimulants. The subjects were also asked to present associations and emotions evoked in them by the given landscape, which allowed to sort the landscapes in the emotions matrix of Russel and Lanius (see Młynarczyk, Potocka 2011).

The research included three different lakescapes. Landscape A depicts the western shore of Lake Zbąszyńskie, developed agriculturally and partly covered with forest. Landscape B presents the view of the beach in Augustow with a water ski lift, tribunes and technical facilities (see Piotrowski 2012). That landscape was studied among others in order to see whether the lift is visible from the surface of the lake. Landscape C shows panorama of Lake Ślesińskie and the beach located in middle-eastern part of the lake (Fig. 2).

The basic material acquired in the research was video attention tracking footage. It allows a real-time analysis of which elements were watched by the subjects, in what order and for how long. The research also provided a gaze plot presenting saccades (solid lines) and fixations (circles). The bigger the circles, the longer the observer was looking at a given point. The outcome of the research is also the opacity map - the more transparent the opaque layer, the greater attention was paid to the given area.

The other type of the acquired picture is the heat map, which with the use of colors presents the intensity of attention of all the subjects. The more the color shifts towards red and the area is "warmer", the more attention was focused on it (Fig. 3).

20 Nearly $70 \%$ of subjects were women, and the average age was 24 . The respondents came mainly from Wielkopolska, $83 \%$ were city dwellers; over $80 \%$ of respondents had higher undergraduate education, and the remaining persons had secondary education.
The gaze plot analysis (Fig. 3) allows to confirm that according to the theory of vision the landscapes were watched not in a continuous and even manner, but with separate gazes automatically drawn by points of interest (viewing space, one divides it into fields or zones of view). Outside such points we see with blurred, peripheral vision, but - what may be considered a disadvantage of eye-tracking - this kind of vision is not recorded by the device. Human vision specializes in detecting contrasts, straight lines and shapes, and is also adjusted well to searching for sources of organization of perception field, as focal points. In the case of vast plain landscapes, the only way to view them is to look along the line of the horizon.

This is confirmed by the presented research results. The heat maps of limnic landscapes presented above (Fig. 3) show that the area of concentrated gaze was the shoreline. This phenomenon is in compliance with the theory of vision, which postulates that the observer focuses attention on distinct borders (lines) in landscape (Strzemiński 1974). The eye follows the direction indicated by a cluster of lines leading towards the inside - most commonly it is the sight of a road or path (Patoczka 1999, p. $60)$. The remaining borders also constituted areas of gaze concentration (the line of contact between water and reed or between water and beach), because of great contrasts between colors and textures. In landscape $\mathrm{A}$, the gaze was concentrated on the sailboat sailing on the reservoir. The

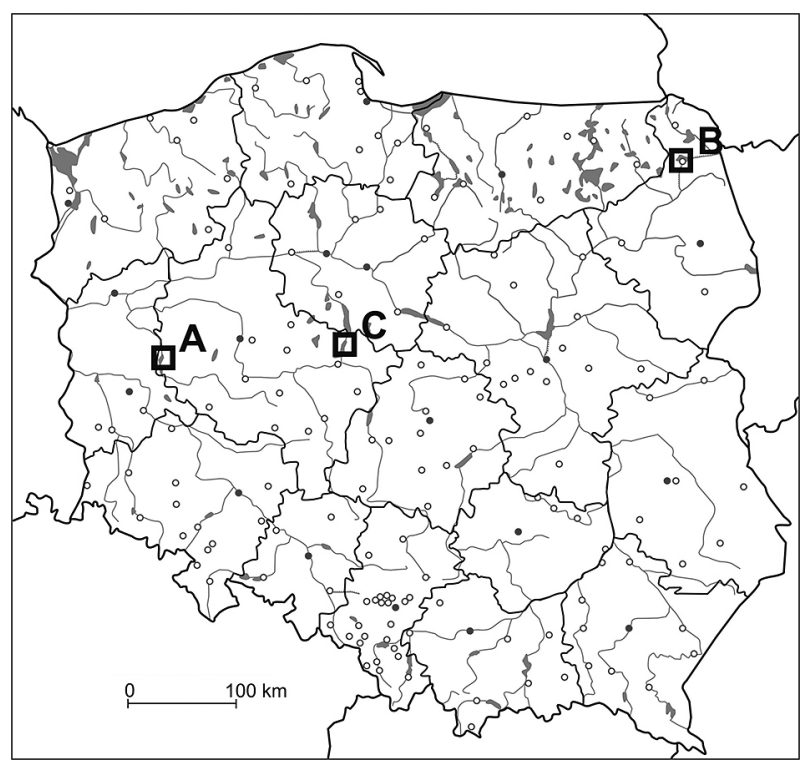

Fig. 2. Location of considered lakescapes in Poland 

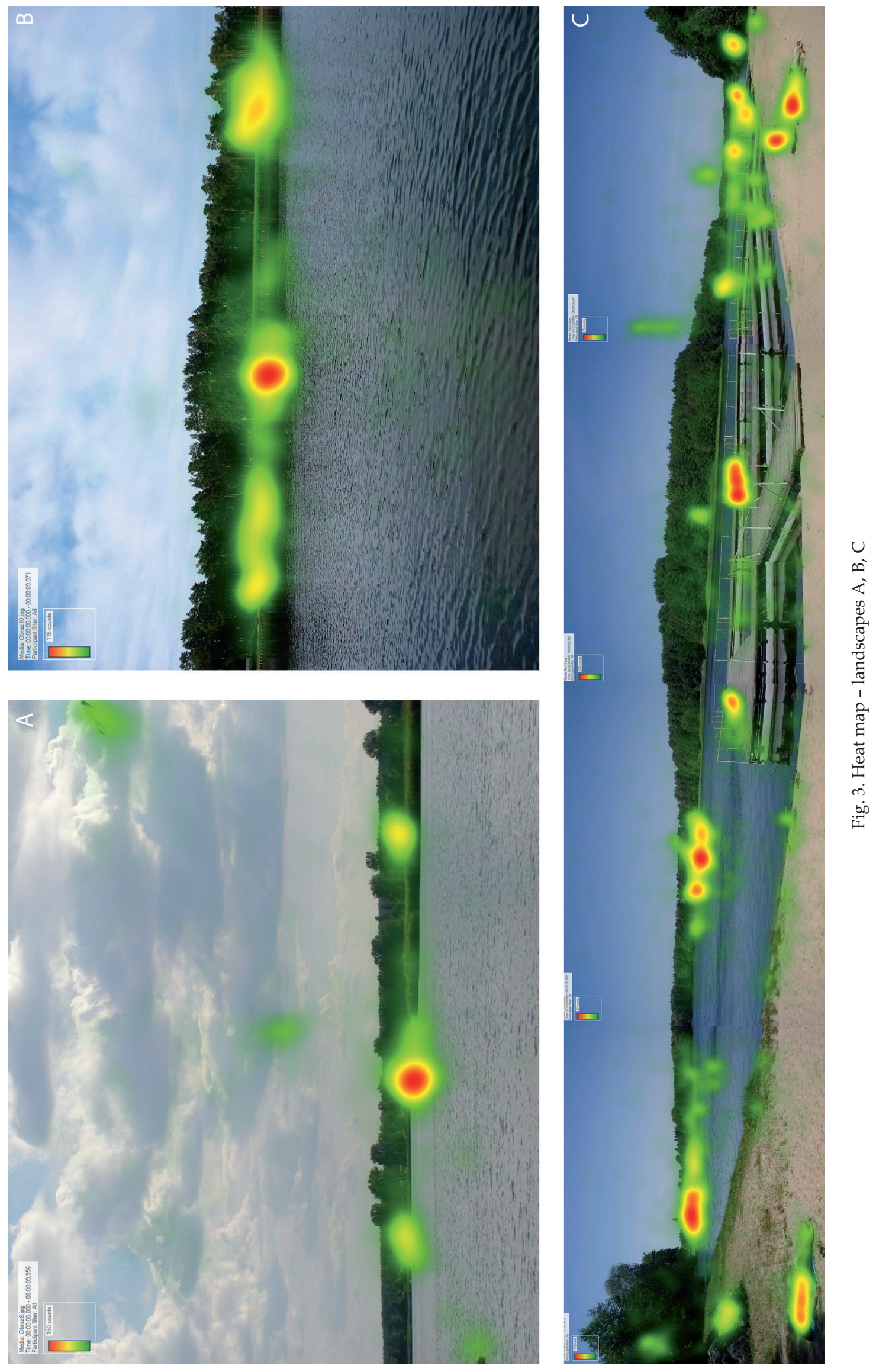
sailboat may be deemed the main focus, which draws the most gazes. Such focuses contain the most convergences - in terms of lines, light and shadow, color, movement, etc., which causes the sight to be automatically drawn and kept by them (Strzemiński 1974). Gazes concentrate in the socalled perspective convergence points, more or less apparent in a landscape. In the landscape A the sight was drawn by two colored accents in the background - a fragment of a cultivated field (left side of the photo) and a fragment of the roof of the building (right side of the photo), as well as the clouds (just like the color of the sky, the weather, sun and lighting, they were underlined by over two thirds of respondents) ${ }^{21}$. In the landscape of Lake Necko (B), sight was drawn by the shore with the lift, especially by the technical buildings. The respondents most often concentrated their gaze on the lift operator's workplace in the central part of the photo, as well as on the lift pylon to the right and on the piers to the left of the operator's workplace. As far as intensity of interest is concerned, the second element was the water surface in the foreground (see Piotrowski 2012). The vast water surface, as monotonous, was usually assessed negatively.

One necessary element of lakescape drawing the sight of a tourist is another tourist (recreationist). It is confirmed by the results of the landscape C examination (Lake Ślesińskie panorama). The respondents most often looked at people resting on the beach, apart from lighter-colored points at the opposite shore.

The respondents paid attention to the whole of the landscape - its composition, colors and harmony. They associated the presented views with the possibility to exercise different forms of tourism (cycling, walking, agrotourism). Landscapes evoked reminiscences - of childhood, of summer.

21 We may speak of the clouds phenomenon. Specific attitude of a man towards clouds has its roots in the childhood. Children raised in religious atmosphere see a holy world in the clouds, the home of God, saints and angels. And this world is positive, joyous. Adults retain this positive, symbolic attitude, though of course it has a poetic and fantastic dimension (Gołaszewska 2000). Looking into the sky, a man expects diversity, and that is why the sky with floyds will be more attractive than a uniform, blue space (see Gołaszewska 2000).

\section{Conclusions}

It is good to live in non-obvious lands, as their borders encompass more space than geography indicates. There are theabysses of the unknown, there is the infinityof speculation, the escaping horizon of imagination and mirage of sweet superstition that simple reality can never live up to.

(Stasiuk 2006, "Going to Babadag")

The research concerning tourist landscape (lakescape) is complicated due to complexity of mere landscape concept as well as to multithreaded nature of the perception process. The key question is the way the lakescape is considered - as subject or as object. As subject - being an objective, real view of the lake and its surroundings (a part of space where tourist phenomena occur), or as object - subjectively, as something perceived by the tourist, different from their place of residence existing in their mind. It needs to be stressed that the tourist is not only an observer, but also a part of landscape.

In the first part of the article an attempt was made to define the role of water in landscape and in human life. The questions raised included the meaning of water in the following aspects: historical, cultural and philosophical (existential problems) as well as psychological (landscape as a source of emotions, obvious sensual experiences).

The presented analyses also attempted to define which features should be characteristic to lakescape in order to arouse positive aesthetic sensations among tourists, at the same time emphasizing the extremely subjective sense of beauty and aesthetics. The results of the research conducted by environmental psychologists (Kaplan, Kaplan 1998, Bell 2004) indicate that a man in general prefers natural landscapes (though the concept of being natural is not unequivocal) which are harmonious and diverse - horizontally (developed shoreline, diverse land coverage) and vertically (high lakeshores), with vegetation which does not cover the view, but at the same time provides safety and intimacy. 
A considerable part of the article was devoted to multisensory perception. As Rodaway (1994) wrote, all senses are geographical - they help people to orientate themselves in space, to become aware of spatial relations and to appreciate advantages of particular places. The conducted research confirms that landscape perception depends on many external factors and internal factors as well, connected with features of personality of the person viewing the landscape and their present predispositions. The main emphasis was put on visual perception, since the sense of vision is dominant. To identify the landscape elements which draw the sight eye-tracker was used - a device recording spontaneous movement of the eyeball (so far not used in landscape research, but allowing to make such research objective to considerable extent). The analyses results show that the areas of concentrated gaze were distinct borders in landscape, e.g. the line of contact between water and land, which was connected with great contrasts of colors and textures. Gaze was also focused on gaze points e.g. a sailboat, clouds or other people (sunbathing). It is worth to emphasize that the acquired results confirm the basic assumptions of the theory of vision of Strzemiński (1974).

The above considerations prove that the research of landscape perception are multithreaded and interdisciplinary. They also show what possibilities gives the application of technologies so far used for other research areas (completed of course with traditional surveys) for the purposes of tourist landscape.

\section{References}

Bartkowska J., 2009. Internauta jedzie na wakacje. Ale dokad $i$ jak? Badanie portali turystycznych. On-line: www.symetria. pl.

Bell P.A., Greene Th.C., Fisher J.D., Baum A., 2004. Psychologia środowiskowa, Gdańskie Wydawnictwo Psychologiczne, Gdańsk.

Bogdanowski J., 2000. Badania i ochrona krajobrazu kulturowego. In: A. Tomaszewski (ed.), Badania i ochrona zabytków w Polsce w XX wieku, TOnZ, Warszawa.

Böhme G., 2002. Filozofia i estetyka przyrody w dobie kryzysu środowiska naturalnego, Oficyna Naukowa, W-wa.

Choiński A., 2007. Limnologia fizyczna Polski. Wyd. Naukowe UAM, Poznań.

Chojnicki Z., 1999. Podstawy metodologiczne i teoretyczne geografii. Bogucki Wydawnictwo Naukowe, Poznań.

Dobre na pierwszy rzut oka. Wiadomości Turystyczne 4, 1628.02.2010. On-line: http:/ /typo3.fly.pl.
Duchowski A.T., 2007. Eye Tracking: Methodology, Theory and Practice, Springer, London.

Duda-Gromada K., 2009. Turystyka jeziorna - nowa forma turystyki? Prace i Studia Geograficzne 42.

Emerson R.W., 2005. Natura. Wyd. Zielona Sowa, Kraków.

Encyklopedia wody. On-line: http://www.waterencyclopedia.com/St-Ts/Tourism.html, accessed: 31 January 2010).

Gołaszewska M. (ed.), 2000. Poznanie i doznanie. Eseje z estetyki ekologii, TAiWPN UNIVERSITAS, Kraków.

Hall C.M., Harkonen T. 2006. Lake tourism: an introduction to lacustrine tourism systems. In: C.M. Hall, T. Harkonen (eds.) Lake tourism. An integrated approach to lacustrine tourism systems. Aspects of tourism, 32: 3-26.

Judycki S., 2008. Świat zmystowy $i$ creatio continua, Internetowe Czasopismo Filozoficzne Diametros (przy Instytucie Filozofii Uniwersytetu Jagiellońskiego), 15. Online: www.diametros.iphils.uj.edu.pl.

Kaplan R., Kaplan S., 1989. The Experience of Nature: A Psychological Perspective, Cambridge Univ. Press. On line: books.google.pl.

Kaplan R., Kaplan S., Ratz K., Dakhil M., 1988. Recreational choices and environmental preference. Annals of Tourism Research 15 (3): 357-370.

Kaplan R., Kaplan S., Ryan R.L., 1998. With People in Mind: Design and Management of Everyday Nature. Island Press.

Klawiter A., 1999. O słyszeniu przedmiotów, Poznańskie Studia z Filozofii Humanistyki 5(18). Wyd. Zysk i S-ka, Poznań.

Kondracki J., 2009. Geografia regionalna Polski. PWN, W-wa.

Kowalczyk A., 1992. Metodologia i metodyka badań percepcji krajobrazu z punktu widzenia potrzeb turystyczno-wypoczynkowych. In: Metody oceny środowiska przyrodniczego GEA, 2.

Kowalski P., 2002. Woda żywa. Towarzystwo Przyjaciół Ossolineum, Wrocław.

Krzymowska-Kostrowicka A., 1997. Geoekologia turystyki i wypoczynku. PWN, W-wa.

Krzymowska-Kostrowicka A., 1999. Kulturowe uwarunkowania oceny i waloryzacji krajobrazów turystyczno-rekreacyjnych. In: M. Pietrzak (ed.), Geoekologiczne podstawy badania i planowania krajobrazu rekreacyjnego. Problemy Ekologii Krajobrazu, 5.

Lisowski A., 2003. Koncepcje przestrzeni w geografii człowieka. WGiSR, UW, Warszawa.

Macnaghten P., Urry J., 2005. Alternatywne przyrody. Nowe myślenie o przyrodzie $i$ społeczeństwie. Wyd. Naukowe Scholar, W-wa.

Młynarczyk Z., Potocka I., 2010. Próba obiektywizacji oceny krajobrazu turystycznego przy wykorzystaniu zjawiska sakad. In: Z. Młynarczyk, A. Zajadacz (eds.), Uwarunkowania i plany rozwoju turystyki. Turystyka i Rekreacja - Studia i Prace, VII. Bogucki Wydawnictwo Naukowe, Poznań.

Młynarczyk Z., Potocka I., 2011. Możliwości wykorzystania eye-trackingu w badaniach krajobrazu turystycznego. In: M. Durydiwka, K. Duda-Gromada (eds.), Przestrzeń turystyczna - czynniki, różnorodność, zmiany. WGiSR, Uniwersytet Warszawski, Warszawa.

Nasar J.L., Li M., 2004. Landscape mirror: the attractiveness of reflecting water. Landscape and Urban Planning 66.

Papp S., 2002. Przestrzeń. TAiWPN UNIVERSITAS, Kraków.

Patoczka P., 1999. Uwagi o rysowaniu wnętrz krajobrazowych. Politechnika Krakowska, Kraków.

Pietrzak M., 2008. Krajobraz multisensoryczny i metody jego oceny. In: Z. Młynarczyk, A. Zajadacz (eds.), Zasoby antropogeniczne. Krajobraz. Ruch turystyczny. Turysty- 
ka i Rekreacja - Studia i Prace 2, Wyd. Naukowe UAM, Poznań.

Pietrzak M., 2010. Krajobraz rekreacyjny - istota, treść i zakres pojęcia. In: Richling A. (ed.), Krajobrazy rekreacyjne - kształtowanie, wykorzystanie, transformacja. Problemy Ekologii Krajobrazu. 27.

Piotrowski K., 2012. Wptyw wyciagu nart wodnych na wybrane elementy środowiska przyrodniczego i aktywność turystycznorekreacyjna na przyktadzie Augustowa. Ph. D. Thesis.

Plit F., 2010. Pięć nurtów badań krajobrazowych w Polsce czy jest w nich miejsce dla krajobrazów rekreacyjnych? In: A. Richling (ed.), Krajobrazy rekreacyjne - ksztattowanie, wykorzystanie, transformacja. Problemy Ekologii Krajobra$\mathrm{zu}, 27$.

Potocka I., 2007. Z badań nad turystyka w rynnie jezior kórnicko-zaniemyskich. Pamiętnik Biblioteki Kórnickiej, 28: 37-60.

Przecławski K., 2001. Cztowiek a turystyka. Zarys socjologii turystyki. ALBIS. Kraków.

Richling A., 2010. O krajobrazie raz jeszcze. Czy istnieją krajobrazy rekreacyjne? In: A. Richling (ed.), Krajobrazy rekreacyjne - ksztattowanie, wykorzystanie, transformacja. Problemy Ekologii Krajobrazu 27.

Richling A., Solon J., 2011. Ekologia krajobrazu. PWN, W-wa.

Skarżyński Z., 1992. Ocena walorów estetycznych krajobrazu okolic Piecek na Pojezierzu Mazurskim. In: Metody oceny środowiska przyrodniczego. GEA 2.

Smith S., 2003. Lake tourism research: themes, practice, and prospects. In: T. Härkönen (ed.), International lake tourism conference, 2-5 July, Savonlinna, Finland. Savonlinna Institute for Regional Development and Research 5.
Sołowiej D., Kozłowska M., Sąsiadek W., 1997. Identyfikacja konfliktów człowiek-środowisko przyrodnicze w jeziornych systemach rekreacyjnych. In:A. Choiński (ed.), Wptyw antropopresji na jeziora. Materiały z konferencji naukowej 2 XII 1997. Wyd. Homini, Poznań-Bydgoszcz.

Stachowski J., 1993. O pojmowaniu przestrzeni w geografii turyzmu. Acta Universitatis Nicolai Copernici, Geografia XXIV, 82.

Stasiuk A., 2006. Jadąc do Babadag. Świat Książki - Bertelsmann Media, Warszawa.

Stróżewski W., 2002. Wokót piękna: szkice z estetyki. Universitas, Kraków.

Strzemiński W., 1974. Teoria widzenia. Wyd. Literackie, Kraków.

Śleszyński P., 1997. Z badań nad fizjonomią środowiska przyrodniczego. Prace i Studia Geograficzne 21.

Tuohino A., 2003. In search of the spirit of the lake. Lakes as an opportunity for tourism marketing. In: T. Härkönen (ed.), International lake tourism conference, 2-5 July, Savonlinna, Finland. Savonlinna Institute for Regional Development and Research 5.

Urry J., 2007. Spojrzenie turysty. PWN, W-wa.

Winiarski R., Zdebski J., 2008. Psychologia turystyki. Wyd. Akademickie i Profesjonalne, W-wa.

Zagajewski A., 2009. Niewidzialna ręka. Wyd. Znak, Kraków.

Zajadacz A., Potocka I., 2010. Percepcja walorów turystycznych przez osoby niesłyszące na tle słyszącej części społeczeństwa w Polsce. Turystyka i Hotelarstwo 16. 